\title{
Effectiveness of Community-Based Soil and Water Conservation in Improving Soil Property in Damota Area, Southern Ethiopia
}

\author{
Mamush Masha $\mathbb{D}^{1,2}$ Teshome Yirgu, ${ }^{2}$ Mulugeta Debele, ${ }^{2}$ and Mengie Belayneh $\mathbb{D}^{1,2}$ \\ ${ }^{1}$ Department of Geography and Environmental Studies, Mettu University, Mettu, Ethiopia \\ ${ }^{2}$ Department of Geography and Environmental Studies, Arba Minch University, Arba Minch, Ethiopia \\ Correspondence should be addressed to Mamush Masha; prssh-1009-10@amu.edu.et
}

Received 27 January 2021; Revised 10 March 2021; Accepted 8 April 2021; Published 22 April 2021

Academic Editor: Amaresh K. Nayak

Copyright (C) 2021 Mamush Masha et al. This is an open access article distributed under the Creative Commons Attribution License, which permits unrestricted use, distribution, and reproduction in any medium, provided the original work is properly cited.

\begin{abstract}
Soil and water conservation (SWC) is being advocated as an integral part of agricultural land management as it not only controls/ minimizes soil erosion but also restores/rehabilitates the degraded lands. The purpose of this study was to evaluate the impact of soil and water conservation practices in improving soil fertility in the agricultural landscapes of the Damota area, southern Ethiopia. Forty-eight soil samples (both disturbed and core samples) were collected from the conserved and adjacent nonconserved plots. The significance analysis test was performed using analysis of variance. The result of the study showed that higher mean values of soil physicochemical properties were observed in the conserved plot than its nonconserved counterpart. The mean differences of organic carbon, total nitrogen, cation exchange capacity, and exchangeable $\mathrm{K}^{+}$and $\mathrm{Ca}^{2+}$ between conserved and nonconserved plots were statistically significant at the $P<0.01$ level. Besides, available phosphorous and bulk density were significant at $P<0.05$, but the effect of SWC practices was not found significant on soil texture, soil $\mathrm{pH}$, and exchangeable $\mathrm{Na}^{+}$and $\mathrm{Mg}^{2+}$ content of the soil in the Damota area. Community-based soil and water conservation practices have improved the soil fertility in agricultural landscapes, although significant results have been observed in some fertility indicators. Therefore, strengthening the implementation of conservation measures by participating in all stakeholders is recommended. Supporting physical structures by agronomic and vegetative measures and continued maintenance can bring better results.
\end{abstract}

\section{Introduction}

Land is an important bridge to achieve the UNs sustainable development goals linked with food, water, climate, and health; as a result, high pressure on this resource is to be expected $[1,2]$. Therefore, avoiding further land degradation, harmonized use of the functioning of the land and soilwater systems and changing the stakeholders' attitude is vital [1]. However, land degradation and associated consequences has diminished the productive potential of the land [3], and one-third of the world's agricultural land has been degraded and becoming a great challenge to current and future food security [3]. It is a threatening environmental problem in Ethiopia $[4,5]$.

Soil erosion is identified as the foremost cause of land degradation mainly in the rainfed agricultural landscapes of
Ethiopia [6]. Water-induced soil erosion is the removal of top fertile soil as a result of erosive rainfall and consequent runoff [1]. It is a global environmental problem that exerts influence on the productivity of agriculture and other natural ecosystems and threatens the livelihoods of most smallholder farmers $[3,4]$. The problem particularly in the highland portion of the country is among the highest at the world level $[7,8]$. Besides, it is becoming a threat to sustainable agriculture in these areas $[4,9]$.

Although, soil erosion initiated and further exacerbated by several natural and manmade factors [10], the problem is highly associated with anthropogenic factors [4-6]. Several previous research results reported that the problem of soil erosion has been exacerbated along with population pressure and associated factors [4-6, 11]. The modification of the natural cover of the land related with poor land management 
methods makes the area more susceptible to soil erosion $[5,11]$. The dissected nature of the topography together with intense rainfall also contributes for soil erosion by water [4], particularly after the modification of the land by human activities.

The problem is predominantly severe on cultivated sloping lands as these areas are highly vulnerable to easy removal of the uppermost soils by running water [12]. Population pressure and its related consequences, such as continuous cultivation, cultivation of marginal lands, and overgrazing, can cause greater removal of soil nutrients by runoff erosion. Furthermore, Tadele et al. [13] indicated that the major causes of land degradation in Ethiopia are population increase, deforestation, and unsustainable agricultural practices. Clearing of natural vegetation, overcultivation, and removal of crop residues have led to the greatest decline in soil organic carbon content [14]. The agricultural practices in the country are characterized by backward production technologies, small fragmented land, and poor land management practices [13].

The neutrality land degradation referring to making the soil erosion rate and formation rate at equilibrium point is essential to realize sustainable development goals related to land [1]. However, several research results reported recently implies that realizing land degradation neutrality has been facing greater challenge. For instance, the highlands of Ethiopia are estimated to lose $940,893,165$ tons of net soil annually [6]. The rate of soil loss ranges from 37 to $246 \mathrm{tha}^{-1}$ $\mathrm{yr}^{-1}$ due to the variations in the site-specific biophysical conditions of the area and management practice $[15,16]$. In addition to its strong impact on soil removal, gully erosion damaged (kept out of production) a considerable amount of cultivable and cultivated land [17] such as $2.5 \%$ of the Warke watershed [18] and $2.13 \%$ of the Teter watershed [17]. As a result, soil erosion causes a significant negative impact on soil nutrient, agricultural production, and economic problems and painful environmental damage in the country [19]. In relation with these related problems, the livelihoods of approximately $66 \%$ of the population have been affected [4]. Therefore, soil resources should be protected in a sustainable manner to sustainably insure food security, energy, and water availability $[1,20]$.

In these regards, the government of Ethiopia and development partners have made a considerable effort to implement SWC practices since the ending of the 1970s and 1980s $[11,16,21,22]$. Soil conservation is a nonnegotiable means of improving soil fertility and land management in agriculture-dependent developing countries [20]. The main purpose of the initiatives was to reduce soil erosion, restoring soil fertility, rehabilitate the degraded land, and increase agricultural productivity [23]. The initiatives at the beginning (the 1970s and 1980s) were targeting social security in drought-affected areas but not focused on resource management [24]. However, for the late 2-3 decades, different SWC conservation measures were implemented in most parts of the highlands. Conservation measures were both indigenous and conventional such as traditional furrows, soil bunds, stone bunds, and fanya juu terraces, bench terraces, cutoff drains, check dams, grass strips, and tree plantations [25].
However, several research findings recently reported that soil erosion has been increasing with time. Soil erosion remains the main agricultural and environmental challenge in the highlands of Ethiopia $[4,26]$. For instance, over the period 1995-2005, the net amount of soil erosion increased from 130 to 182 million metric $t$ [27]. The agricultural production was almost stagnant ( $0.4 \%$ increase) against the high spatial expansion of cultivated land (5.7\% increase) in the period between 1991 and 2003 [27]. This indicates that the achievements are below the expectations [26].

Efforts were made to assess the effects of SWC practices in different parts of the country so far [21], but the lion share of these studies is concentrated in the northern and eastern rainfall-scarce parts of the country $[11,28]$. However, the efforts made in the southern high rainfall areas are minimal. Besides, common agreements were not observed on the effectiveness of conservation measures reported so far [25], and the achievement varies over space [21] for various reasons. Some stated that conserved lands significantly reduced runoff and soil loss $[25,29,30]$ and comparatively better soil fertility compared to the nonconserved counterpart $[5,31,32]$. On the other hand, some argued that soil loss concentration was not reduced due to SWC practices [33]. Besides, SWC practices perform differently in different rainfall regimes [22]. Thus, local agroecology specific SWC impact assessment is essential. These can help to better understand the impacts of SWC measures and make them sustainable [32].

In the Damota area of the Wolaita zone, as part of the Ethiopian highlands, soil erosion has been a threatening problem for agricultural soil and its productivity. As a result, SWC has been implemented by government-led masscommunity mobilization for the last two to three decades; however, the problem of soil erosion is continued to be the greatest challenge. Thus, evaluating the impacts of SWC measures practices is top vital to learn lessons from previous successes and identify the challenges for future better conservation planning. Evaluating the impacts of SWC practices on soil properties is essential to better scale-up its best practices and improve its limitations [32]. However, although soil erosion is still high, the effectiveness of SWC practices has not been evaluated in the area. Therefore, the purpose of this study was to evaluate the impacts of SWC practices in improving soil fertility in the Damota area, southern Ethiopia.

\section{Materials and Methods}

2.1. The Study Area. Damota area lies $6^{\circ} 44^{\prime} 30^{\prime \prime}$ to $7^{\circ} 9^{\prime} 49^{\prime \prime} \mathrm{N}$ latitude and $37^{\circ} 34^{\prime} 47^{\prime \prime}$ to $37^{\circ} 98^{\prime} 58^{\prime \prime}$ E longitude in the Wolaita zone of the Southern Nations Nationalities and Peoples Regional State. The area is located $395 \mathrm{~km}$ from the south of Addis Ababa, the capital city of Ethiopia. It covers an area of $12,098 \mathrm{~km}^{2}$. The area is dominated by rugged and elevated topography. It comprises Boloso Sore, Damot Gale, and Sodo Zuriya districts centering Damota Mountain (Figure 1). According to the Food and Agricultural Organization [34] soil map, Eutric Nitosols, Plinthic Ferralsols, Eutric Cambisols, Ochric Andosols, and Haplic Xerosols 


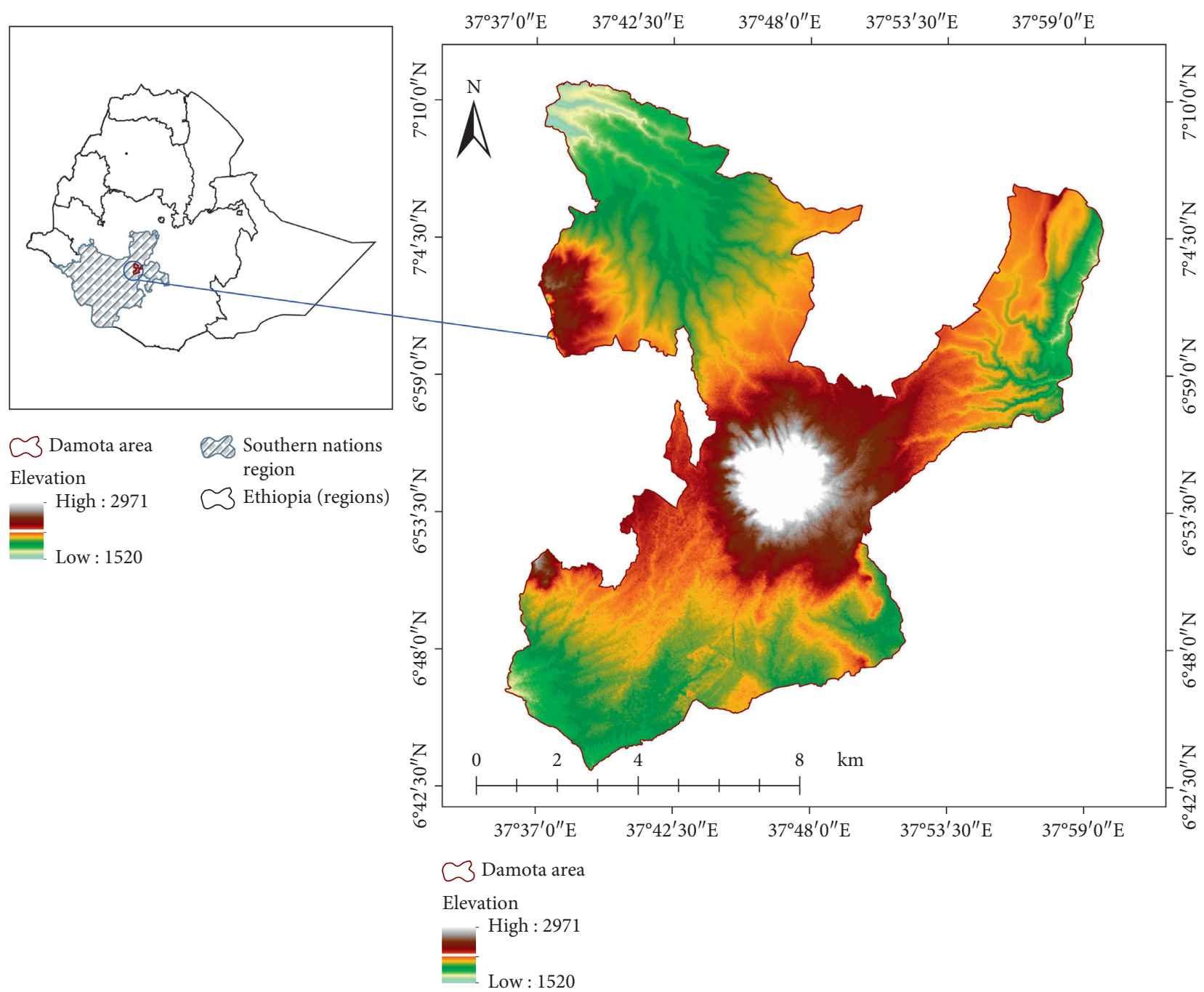

FIgURE 1: Location map of the study area (Damota area), Southern Ethiopia.

dominate the soil of the study area. Reddish-brown Eutric Nitosols found on the steep slopes and reddish black Humic Nitosols are prevalent in the flat areas, with a rainfed and a few irrigation systems.

The mean monthly minimum and maximum temperatures are $14^{\circ} \mathrm{C}$ and $20^{\circ} \mathrm{C}$, respectively (Figure 2). The area receives a long-term average annual rainfall of approximately $1,200 \mathrm{~mm}$ in a bimodal rainfall pattern. The main rainfall season is from June to September (locally called Kiremt) and a small rainfall season from February to March (locally called "Belg"). According to the agroclimate classification system, the area is characterized by Dega and Woina Dega zones with an altitude ranging from 1480 to 2855 meters above the sea level. In the area, cropland is the dominant land-use type. However, grazing land, bush, and woodland are also found in the area. Small-scale subsistence mixed farming is the main livelihood system in the area. The most commonly cultivated crops in the area are barley (Hordeum vulgare), wheat (Triticum vulgare), maize (Zea mays), teff (Eragrostis tef), horse bean (Pisum sativum), and chickpeas (Cicer Arietinum). The Damota area is among the

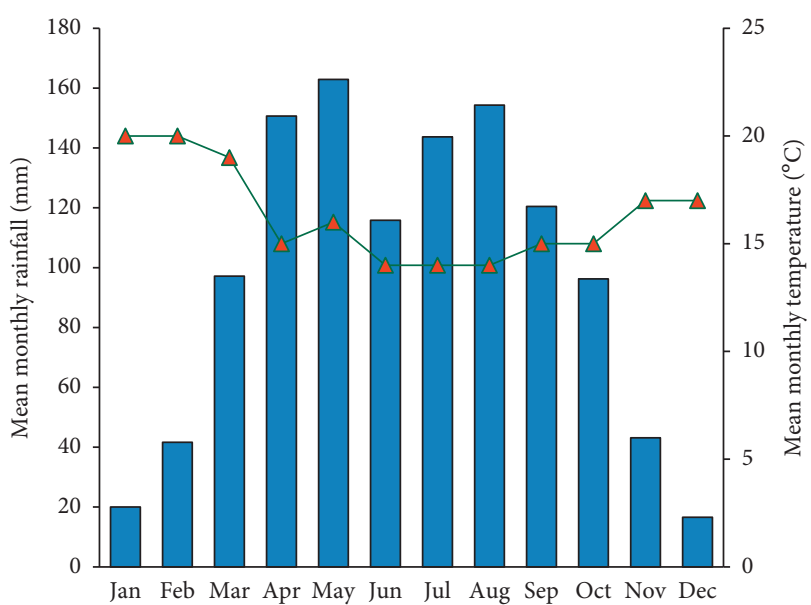

Figure 2: Monthly average rainfall $(\mathrm{mm})$ and temperature $\left({ }^{\circ} \mathrm{C}\right)$ in the study area.

highly populated areas of the country. For instance, in 2007, the population of the Wolaita zone was 1,107,079, and rural density varied from 167 persons per square kilometer in the 
midlands to 746 persons per square kilometer in the highlands [35]. The population density of the area exceeds the national average by 2.5 times.

2.2. Data Collection and Soil Sampling. Prior to actual soil sampling, sites having conserved and adjacent nonconserved plots were identified through the reconnaissance survey method. Besides, Google Earth Pro was also consulted for site selection. This is because soil samples must be taken from comparable plots that have most likely similar biophysical characteristics such as slope, climate, soil, and land use. The area was categorized into three relative slope positions such as upslope midslope and lower slope. A total of 48 soil samples (both disturbed and core samples) were taken at a depth of $0-20 \mathrm{~cm}$ by delineating $10 \times 10$ meters plot size. Of which, 24 were taken from conserved plots (cultivated fields treated with most commonly implemented conservation structures such as either soil bund, stone bund, or fanya juu), and the remaining 24 were from adjacent nonconserved plots. Eight soil samples were taken from each slope position (upslope, midslope, and lower). In other words, the soil sampling can be expressed as 2 treatments $\times 3$ slope positions $\times 8$ replicates. Augur and core sampler was used to collect the disturbed and undisturbed (core) samples, respectively.

Besides, to support the laboratory result, socioeconomic data have been collected from sample farmer households. For the collection of socioeconomic data concerning SWC and related limiting factors, three farmers groups (upslope, midslope, and lower slope positions) with six members in each were selected for focus group discussion. Sample farmers were selected by considering their age, involvement in SWC implementation, planning, and training purposively.

2.3. Soil Laboratory Analysis. The collected subsoil samples from five corners of the delineated plot were mixed to make a single composite sample for laboratory analysis. It was then air-dried, grinded, and passed through a $2 \mathrm{~mm}$ sieve before the laboratory analysis. Samples for organic carbon and total nitrogen analysis were further sieved by a $0.5 \mathrm{~mm}$ sieve. Selected soil physicochemical properties such as soil texture (soil particle size proportions), bulk density, soil reaction, total nitrogen, organic carbon, available phosphorus, cations exchange capacity, and exchangeable bases were analyzed using standard laboratory procedures at Southern National Regional State Agriculture Office, Wolaita Sodo Soil Laboratory. The core sampling technique described by Black et al. [36] was used for soil bulk density determination. The determination of soil particle size proportions was performed using the Bouyoucos hydrometer method [37], and textural classes were determined based on the procedure of the USDA system of textural classification. Soil $\mathrm{pH}$ was determined by a $\mathrm{pH}$ meter using a $1: 2.5$ soil: water ratio [38]. The modified Walkley and Black technique described by [37] were used for the determination of soil organic carbon (SOC) concentration. The total nitrogen (TN) content of the soil was determined by using the modified
Kjeldahl methods [37]. The Olsen extraction method was applied for the determination of available phosphorus (Av. $\mathrm{P}$ ) in the soil [38]. The $\mathrm{NH}_{4} \mathrm{OAC}$ process determined the exchangeable bases and cation exchange capacity (CEC). The $\mathrm{Ca}^{2+}$ and $\mathrm{Mg}^{2+}$ were determined by the atomic absorption spectrophotometer, whereas $\mathrm{Na}^{+}$and $\mathrm{K}^{+}$were determined by the flame photometer procedure.

2.4. Statistical Data Analysis. One-way ANOVA was used to test the significant mean differences of soil physicochemical properties between conserved and nonconserved plots. Pearson coefficient of correlation was applied to see the interrelationship between soil properties. The statistical analysis was operated using the Statistical Package for Social Scientists (SPSS) version 20 software.

\section{Results and Discussion}

The impacts of SWC measures on soil fertility indicators were evaluated using analysis of variance. Before the analysis, the homogeneity of variances and normal distribution of the data were tested using Levine's test and the Shapiro-Wilk test. Levine's test was conducted to see the violation of equality of variances and the Shapiro-Wilk test for the distribution of the data, as these are the most important assumptions of ANOVA. In this regard, the homogeneity of variance assumption for some of the soil properties such as soil reaction, exchangeable bulk density, organic carbon, total nitrogen, and exchangeable $\mathrm{Ca}^{2+}$ was violated. Therefore, the robust test of ANOVA (Welch) was applied. The Welch test is a more appropriate test for normally distributed and balanced data between groups and controls type I error that can probably affect the test result [39].

\subsection{Soil Physical Properties}

3.1.1. Soil Texture. Table 1 provides the soil particle size proportions under conserved (CP) and nonconserved (NCP) plots. The texture of the soil was dominated by clay fractions in both CP and NCP. The highest mean value of clay content was observed in the CP (54.58\%), and the lowest was in the NCP (52.96\%). On the contrary, the average sand content of the soil was higher in the NCP (25.91\%) than that of CP $(24.94 \%)$. The proportion of the soil texture and textural class of the soil was fine-textured and clay in all the CP and NCP. The silt content of the soil constitutes the lowest proportion in both $\mathrm{CP}$ and NCP, although a relatively slightly higher value was observed in the CP. The mean differences of all particle size distributions between CP and NCP were not statistically significant $(P>0.05$; Table 1$)$. This implies that SWC measures did not easily alter the soil textural classes [32], instead the parent material in which the soil was formed is more determinant. Furthermore, Tiki et al. [40] pointed out that the observed nonsignificant differences of texture between CP and NCP might be attributed to the time factor, as plots that spent a relatively short period under SWC treatment (about 20-25 years in the case of Damota area) cannot affect the weathering process to 
TABLE 1: Comparisons of the mean values of sand, silt, clay contents, and bulk density under different SWC treatments and the nonconserved plots.

\begin{tabular}{|c|c|c|c|c|c|c|}
\hline & & & Soil tex & & & $\left.\mathrm{C}^{-3} \mathrm{~m}^{-3}\right)$ \\
\hline & Sand (\%) & Clay (\%) & Silt (\%) & Soil texture & Textural class & BI \\
\hline $\mathrm{CP}$ & 24.938 & 54.583 & 21.646 & Fine & Clay & 1.186 \\
\hline $\mathrm{NCP}$ & 26.617 & 52.958 & 20.483 & Fine & Clay & 1.231 \\
\hline$F$ & 0.920 & 0.974 & 0.213 & - & - & 5.611 \\
\hline$P$ & $0.342^{\mathrm{ns}}$ & $0.329^{\text {ns }}$ & $0.647^{\text {ns }}$ & - & - & $0.022^{*}$ \\
\hline
\end{tabular}

$\mathrm{CP}$, conserved plot; NCP, nonconserved plot; $F, F$-test; $P, P$ value; ns, nonsignificant mean difference $(P>0.05) .{ }^{*}$ and ${ }^{* *}$ implies the mean difference between conserved and nonconserved plots significant at $P<0.05$ and 0.01 levels, respectively.

create a statistically significant variation on soil texture. However, the findings of Guadie et al. [20] in his experimental study revealed that soil bund significantly affected the clay, silt, and sand content of the soil in the Lole watershed, northwestern Ethiopia. The observed discrepancies could be related to the differences in implementation and maintenance of the existing bunds.

Our findings have been in line with the research findings of Belayneh et al. [32] and Tiki et al. [40] who reported a higher mean value of clay content in the conserved Hobene than in the nonconserved Elmo subwatershed. Similarly, Belayneh et al. [32] found high clay and lower sand content in the treated plots than the nontreated counterpart, but the differences did not reach a significant level. The study findings of Tikki et al. [40] reported a nonsignificant variation of soil particle size proportions between the treated and nontreated lands. A relatively high clay content observed in the $\mathrm{CP}$ is primarily the impact of SWC practices on soil erosion as it reduces the removal of soil particles in the conserved plots than that of the high runoff led erosion in the NCP. On the other side, the removal of fine particulates due to erosion in the NCP can increase the sand content of the soil. The land kept under crop cultivation for a prolonged time without any management measure could facilitate unrestricted washing of fine soil particles through runoff [41].

3.1.2. Bulk Density. The mean value of bulk density in the CP and NCP was $1.186 \mathrm{~g} \cdot \mathrm{cm}^{-3}$ and $1.231 \mathrm{~g} \cdot \mathrm{cm}^{-3}$, respectively. This showed that the bulk density was higher in the NCP than that of the CP, and the difference was statistically significant $(P>0.05$; Table 1$)$. This is due to the existence of high organic matter content in the treated plots [42]. The removal of uppermost soil organic materials by runoff might be the reason for the observed high bulk density value in the CP than its NCP equivalent. It is obvious that in the nonconserved cultivated plots, the remnants of plants, crop residues, animal dung, and other accumulations can be easily washed down by rainfall runoff particularly in the high rainfall highland areas of Ethiopia unlike that of the conserved cultivated lands. As a result, variations in presence of these organic materials in the soil can create differences in the bulk density of the soil. Demelash and Stahr [41] observed significantly higher mean values of bulk density in the conserved than the nonconserved land in South Gonder, northwestern Ethiopian highlands. In addition, our findings were also in line with Belayneh et al. [32], Eyayu et al. [43], and Hishe et al. [5] who reported nonsignificant but lower bulk density values in the conserved plots than in nonconserved plots in the Gumara watershed, Tara Gedam catchment, and Middle Siluh valley, respectively.

\subsection{Soil Chemical Properties}

3.2.1. Soil $p H$. The mean values of the $\mathrm{pH}$ of the soil at the $\mathrm{CP}$ (5.82) were higher than that of the NCP (5.74; Table 2). The ANOVA result revealed that the mean difference of soil $\mathrm{pH}$ between CP and NCP was not significant. The result was in agreement with Hishe et al. [5] and Belayneh et al. [32] who reported nonsignificant but relatively higher acidity levels in the nonconserved than conserved lands. The relatively lower mean value in nonconserved plots may be related to excessive rainfall coupled with dissected topography, leaching, and discharge of important soil nutrients, whereas the greater $\mathrm{pH}$ value in conserved plots is related to the reduction of the removal of important minerals. They further explained that the high magnitude of erosion in nonconserved land leaches soluble bases and minerals and subsequently contributes to soil acidity, whereas the less removal of soil organic matter in the conserved land improves the $\mathrm{pH}$ value of the soil. However, according to the acidity rating of Osman [44], the soil under both the SWC treatment and untreated plots was medium acidic. This can be related to the climatic (rainfall) situation of the area as high rainfall strongly and continuously leaches the soil nutrients and basic cations in the humid and subhumid highlands [32, 44]. Besides, the acidity might also be related to the extensive plantation of eucalyptus trees by local residents.

However, on the other hand, Guadie et al. [20] and Siraw et al. [42] found significantly lower soil $\mathrm{pH}$ value (higher acidity) in the conserved than their nonconserved counterparts in the Lole and Tija Baji watersheds, respectively. The removal of soluble basis and organic matter in the nonconserved fields due to water erosion can cause a high $\mathrm{pH}$ value in the controlled plots because removal of cations causes increase of $\mathrm{H}^{+}$ ion in the soil solution [45]. Conversely, Siraw et al. [42] pointed out that the reason for the existence of lower soil reaction is associated with the observed high organic matter content of the soil in the SWC-treated watershed.

3.2.2. Organic Carbon. The average soil organic carbon content in the CP and NCP was 2.265 and $2.042 \%$, respectively. Our study result showed that SWC treatments 
TABLE 2: The significance test of mean differences of soil chemical properties between conserved and nonconserved plots.

\begin{tabular}{|c|c|c|c|c|c|c|c|c|c|}
\hline & \multirow{2}{*}{$\mathrm{pH}\left(\mathrm{H}_{2} \mathrm{O}\right)$} & \multirow{2}{*}{ OC (\%) } & \multirow{2}{*}{ TN (\%) } & \multirow{2}{*}{ Av. P (ppm) } & \multicolumn{5}{|c|}{ CEC and exch. basis $\left(\mathrm{cmol}^{(+)} \mathrm{kg}^{-1}\right)$} \\
\hline & & & & & CEC & $\mathrm{Na}^{+}$ & $\mathrm{K}^{+}$ & $\mathrm{Ca}^{2+}$ & $\mathrm{Mg}^{2+}$ \\
\hline $\mathrm{CP}$ & 5.820 & 2.265 & 0.257 & 8.159 & 36.541 & 0.432 & 0.595 & 12.938 & 11.448 \\
\hline NCP & 5.740 & 2.042 & 0.234 & 7.540 & 34.208 & 0.417 & 0.539 & 11.307 & 10.576 \\
\hline$F$ & 2.487 & 8.033 & 9.867 & 4.717 & 10.088 & 1.039 & 8.359 & 9.387 & 2.481 \\
\hline$P$ & $0.122^{\text {ns }}$ & $0.007^{* *}$ & $0.003^{* *}$ & $0.035^{*}$ & $0.003^{*}$ & $0.313^{\text {ns }}$ & $0.006^{* *}$ & $0.004^{* *}$ & $0.122^{\mathrm{ns}}$ \\
\hline
\end{tabular}

$\mathrm{CP}$, conserved plot; NCP, nonconserved plot; $F, F$-test; $P, P$ value; ns, nonsignificant mean difference $(P>0.05) .{ }^{*}$ and ${ }^{* *}$ implies the mean difference between conserved and nonconserved plots significant at the $P<0.05$ and 0.01 levels, respectively.

brought a statistically significant higher organic carbon in the agricultural soils as compared to the nonconserved counterpart $(P<0.01$; Table 2$)$. This is primarily the result of the SWC effect because it diminishes the loss of fine soil elements and remnants. Besides, the increased biomass accumulation as a result of grass strips and plantations can cause high organic carbon content in the soil of conserved areas [42]. The result was in agreement with Demelash and Stahr [41], Tikki et al. [40], Sinore et al. [46], and Tadele et al. [13] who reported that soil organic carbon content of terraced plots was higher as compared to the nonterraced plots. Similarly, a significantly higher organic matter content was observed in the bund treated fields in the Lole watershed, northwestern Ethiopia, as a result of high sediment accumulation caused by bund terraces and barriers [20].

The availability of soil organic matter can be an important symbol of soil quality because it can positively affect other most soil functions [2]. However, the mean values of organic carbon for both CP and NCP were rated low [47]. This can be primarily attributed to strong soil erosion, continuous cultivation, harvesting crop residues, and animal dung [32]. Limited availability of plant covers causes limited biomass accumulation and consequently affects the organic matter content of the soil [42]. The available forest cover in the Damota area is dominantly plantations including eucalyptus trees, which has little importance for organic carbon, soil erosion, and general ecological restoration.

3.2.3. Total Nitrogen. By using the rating system of tropical soils, the total nitrogen content of the soil in the Damota area has been rated medium [47]. This might be related with lowlevel use of nitrogen containing imputes, plant residues, and manure [20]. The average total nitrogen content at the conserved agricultural soils $(0.257 \%)$ was higher than that of its nonconserved equivalent $(0.234 \%)$. The difference in the average total nitrogen value between $\mathrm{CP}$ and NCP was statistically significant at the $P<0.01$ level (Table 2). This might be attributed to the effect of conservation measures, as it reduces the loss of finer soil particles, increases soil organic carbon, and subsequently increases the concentration of total nitrogen in the conserved soils. The result is relatively in agreement with the findings of Hishe et al. [5] who stated a statistically nonsignificant difference between conservation measures. Several study results in different parts of Ethiopia reported that SWC measures improved the total nitrogen content of the soil. For instance, Hishe et al. [5], Belayneh et al. [32], and Guadie et al. [20] reported a significantly higher mean value of total nitrogen in the conserved fields than that of the nonconserved fields in the northern and northwestern Ethiopian highlands.

3.2.4. Available Phosphorous. The average available phosphorous content of the soil at the CP $(8.159 \mathrm{ppm})$ was higher than at the NCP (7.540 ppm), and the difference was statistically significant at the $P<0.05$ level. This implies that in general, the concentration of available phosphorus in the soil is scarce. Landon [47] indicated that the crops (commonly practiced such as cereals and maize) requirement of available phosphorous was deficient. Although, the soil in the area is deficient in available phosphorous content, better availability was observed at conserved soils. This might be due to the relative effect of SWC on runoff and soil loss in the conserved soils. Similarly, high phosphorous content was observed in the conserved plots than that of nonconserved plots [41]. However, on the contrary, higher but nonsignificant available phosphorous content was observed in the nonconserved plots in the Gumara watershed, northwestern Ethiopia [32]. The same study rationalized that such a variation may occur due to variations application of inorganic fertilizer (diammonium phosphate).

3.2.5. Cation Exchange Capacity (CEC). The CEC content of the soil in both the CP and NCP was evaluated as high in the Damota area following the ranking principles of Landon [47]. This is primarily associated with the parent material of the soil and its characteristics as fine-textured soils are rich in CEC naturally [44]. Besides, positively charged ions (exchangeable basis) are more prevalent in soils with a high accumulation of clay and OM, which consequently have high CEC concentration [48].

As given in Table 2, the highest CEC content of the soil was observed in the $\mathrm{CP}\left(36.541 \mathrm{cmol}(+) \mathrm{kg}^{-1}\right)$ and the lowest was at the NCP $\left(34.208 \mathrm{cmol}(+) \mathrm{kg}^{-1}\right)$. The average means variations of the CEC content of the soil showed a statistically significant difference between CP and NCP at the $P<0.01$ level. This could be due to the effect of management measures that reduced the removal of sediments and limited leaching produced to a certain degree of higher clay content and CEC in the CP. Our finding was consistent with the study results of Selassie et al. [48] and Belayneh et al. [32] who observed higher CEC content in conserved plots than nonconserved lands. The CEC content of the soil is significantly influenced by the implementation of soil and water conservation measures, mainly related with the 
accumulation of sediments and limited removal in the treated fields [20, 45].

3.2.6. Exchangeable Basis $\left(\mathrm{Na}^{+}, \mathrm{K}^{+}, \mathrm{Ca}^{2+}\right.$, and $\left.\mathrm{Mg}^{2+}\right)$. The average values of all exchangeable calcium, magnesium, potassium, and sodium contents of the soil were higher at the conserved plots than their nonconserved counterpart. However, the mean variations between soils in CP and NCP reached statistically significant only for $\mathrm{K}^{+}$and $\mathrm{Ca}^{2+}$ $(P<0.01 ;$ Table 2$)$. The relative abundance of the average exchangeable basis content of the soil under the CP and NCP in the exchangeable complex was $\mathrm{Ca}^{2+}>\mathrm{Mg}^{2+}>\mathrm{K}^{+}>\mathrm{Na}^{+}$in the study area. Although the effect of SWC practices was observed in all exchangeable bases, it was more effective and significant on $\mathrm{K}^{+}$and $\mathrm{Ca}^{2+}$. Our findings were in line with the results of Heluf and Wakene [49] and Belayneh et al. [32] who appreciated the effects of SWC conservation measures on soil erosion that contributed to variations in exchangeable basic in the conserved plots. This was in agreement with Asmamaw and Mohamed [50] who reported high calcium and magnesium content of the soils; which could be attributed to the development of soils from young rocks. Significantly higher exchangeable bases were also observed at plots treated with elephant grasses and susbania than that of the nonconserved plots [46].

In general, SWC measures have an important implication in improving the fertility of the soil in the Damota area, southern Ethiopia. These have been performed through varieties of modifications made by the conservation treatments. Conservation structures reduce the slope of the land $[20,45]$, which strongly determine the velocity of soil erosion [32]. On the other hand, significant amount of soil and runoff can be trapped by the bund furrows [29] and remain within the plot. This plays an important role in protecting and improving the soil condition unlike that of the nonconserved counterparts.

3.3. The Interrelationship among Soil Properties. As indicated in Table 3, the correlation between most of the soil physicochemical properties shows significant results at $P<0.01$ and 0.05 levels. The clay content of the soil creates a positive significant relationship with most of the soil properties such as with silt content $(r=0.608)$, organic carbon $(r=0.480)$, total nitrogen $(r=0.696)$, and cation exchange capacity ( $r=0.783$ ) at the $P<0.01$ level. Soil $\mathrm{pH}$ showed a significant positive correlation with total nitrogen and exchangeable $\mathrm{Mg}^{2+}(P<0.01)$. Similarly, the organic carbon content of the soil in the Damota area positively and significantly varies together with that of total nitrogen $(r=0.779)$, cation exchange capacity $(r=0.432)$, and exchangeable $\mathrm{Ca}^{2+}$ $(r=0.64)$. A positive significant correlation between clay content and organic carbon, cation exchange capacity, and total nitrogen was observed in the Lemo district, southern Ethiopia [46]. Some of our correlation results were also comparable with the findings of Hishe et al. [5] in the Middle Siluh valley of northern Ethiopia.

The Pearson coefficient of correlations result in this study implies that most of the soil's physicochemical properties vary together as the accumulation of the one increases, others will probably increase and vice versa. This is very important if the SWC measures are implemented successfully. Because, soil and water conservation practices control the removal of available soil nutrients on the one hand, but it can also increase some nutrients such as organic carbon, total nitrogen, and others through, for example, plantations of legumes plants and grasses. As a result, the increased accumulation of organic matter and total nitrogen can cause other soil properties to be improved. As also indicated in Sinore et al. [46], the accumulation of high organic matter, cation exchange capacity, and exchangeable basis improve the soil $\mathrm{pH}$. The availability of high organic matter and fine-textured soil can increase the availability of total nitrogen, basic cations, and lower bulk density $[5,46]$. Thus, this is an important lesson that the improvements of soil organic matter, cation exchange capacity, and clay content could also indirectly increase the abundance of mort of the soil physicochemical properties and improve the general soil condition.

\subsection{Limitations of SWC Practices in the Damota Area.} Soil and water conservation is considered to have a significant role in reducing soil erosion and rehabilitation of degraded landscapes. But its implementation process varies in both space and time due to diverse social conditions [21]. As a result, the effectiveness of the implemented SWC effort has not been as planned [26]. Similarly, in the Damota area, soil erosion is still the greatest challenge, and the impacts of SWC measures resulted in significant results on some of the soil fertility indicators.

In this regard, the focus group discussion result indicated that the implementations of SWC measures are influenced by several factors. For instance, poor design, construction, maintenance, and long-term adoption problems by some households were principally stated. Farmers in their interview also verified that the involvement of local farmers in the planning, maintenance, and selection of conservation measures has been very low. Dabi et al. [51] indicated that poor implementation of conservation measures has existed, and still local farmers are not sufficiently involved in the implementation process. Besides, conservation works are mostly targeting area coverage instead of following the recommended standards. During the fieldwork, we observed how local farmers construct conservation measures. Poor soil and water management practices are contributing factors in minimizing soil physical and chemical properties that can negatively affect rural livelihoods. The researchers during onsite observation witnessed irregularities in implementation, poor maintenance, and even spacing, and depth of furrows are not following the recommended. This can have a greater impact on reducing the effectiveness of conservation measures. Due to these and other related limitations, the effectiveness of SWC practices has been limited on some soil fertility indicators.

The result was in agreement with Bekele et al. [9] and Belayneh et al. [32] who confirmed that the effectiveness of SWC measures on some of the soil physical and chemical 


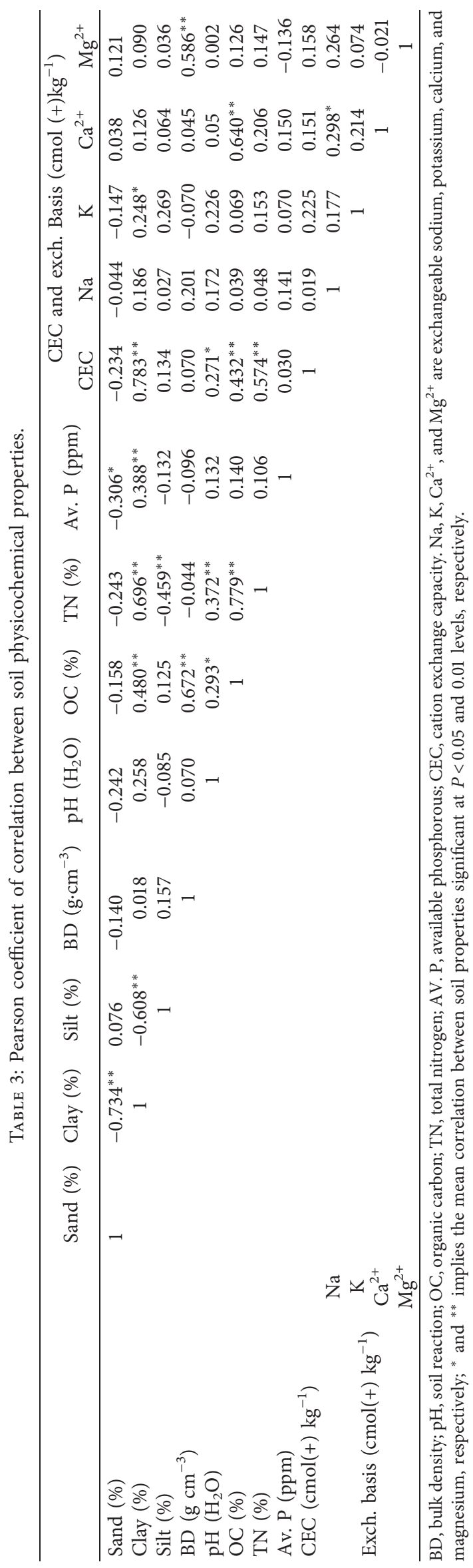


property indicators were influenced by lack of adequate technical skill, poor implementation of conservation measures, and poor maintenance of conservation structures. Similarly, Walie [52] reported the technical skill gap in conservation design, which significantly affects the effectiveness of conservation measures. In this regard, Nael et al. [53] reported the decline of the physical, chemical, and biological qualities of soil resources due to poor soil and water management measures.

\section{Conclusion}

This study examined the impact of SWC practices on selected soil physicochemical properties in the Damota area, southern Ethiopia. Soil and water conservation measures resulted in relatively higher results for most of the soil fertility indicators. Soil and water conservation measures have resulted in significantly higher mean values of soil bulk density, available phosphorous $(P<0.05)$, organic carbon, total nitrogen, cation exchange capacity, and exchangeable $\mathrm{K}^{+}$and $\mathrm{Ca}^{2+}(P<0.01)$. However, the mean differences in soil texture, soil $\mathrm{pH}$, exchangeable $\mathrm{Na}$, and $\mathrm{Mg}^{2+}$ were not significant due to conservation measures. The limited involvement of the local community, low quality, and quantity of implementation, poor level maintenance of structures, and limited use of grasses and plantations as support to physical structures are considered to limit the effectiveness of SWC measures.

Soil and water conservation measures practiced for the last two decades in the Damota area have shown important implications in improving soil physicochemical properties (general soil condition). Therefore, strengthening the efforts currently made by integrating the local government, the community, and other stakeholders should have been recommended. Better implementation of SWC measures in a sustainable manner with continuous maintenance and use of grass strips and agroforestry practices that have both ecological and livelihood importance is vital for more effective results.

\section{Abbreviations}

ANOVA: Analysis of variance

CSA: Central statistical authority

SPSS: $\quad$ Statistical Packages for Social Scientists

SWC: $\quad$ Soil and water conservation

NGO: Nongovernmental organizations

DAs: Development agents

FAO: $\quad$ Food and Agriculture Organization

USDA: United States Department of Agriculture.

\section{Data Availability}

The data used to support the findings of this study are available from the corresponding author upon request.

\section{Conflicts of Interest}

The authors declare that they have no conflicts of interest.

\section{Acknowledgments}

The authors acknowledge the financial support of Arba Minch University. The authors are very grateful to the Wolayta Soddo Soil Testing Laboratory, household heads, and development agents of the Damota area for their support during data collection. The authors would also extend their thanks to enumerators for their effort devoted to collecting data from the respondents with full willingness. Finally, the contribution of the office of Agricultural and Natural Resources Management of Wolayta Zone is highly appreciated.

\section{References}

[1] S. Keesstra, G. Mol, J. De Leeuw et al., "Soil-related sustainable development goals: four concepts to make land degradation neutrality and restoration work," Land, vol. 7, no. 4, p. 133, 2018.

[2] S. D. Keesstra, J. Bouma, J. Wallinga et al., "The significance of soils and soil science towards realization of the united nations sustainable development goals," Soil, vol. 2, no. 2, pp. 111-128, 2016.

[3] N. Haregeweyn, A. Berhe, A. Tsunekawa, M. Tsubo, and D. T. Meshesha, "Integrated watershed management as an effective approach to curb land degradation: a case study of the enabered watershed in northern Ethiopia," Environmental Management, vol. 50, no. 6, pp. 1219-1233, 2012.

[4] H. Hurni, B. Debele, and G. Zeleke, "Saving Ethiopia's soils," in Eastern and Southern Africa Partnership Programme: Highlights from 15 Years of Joint Action for Sustainable Development, A. Ehrensperger, C. Ott, and U. Wiesmann, Eds., pp. 27-30, Centre for Development and Environment, University of Bern with Bern Open Publishing, Bern, Switzerland, 2015.

[5] S. Hishe, J. Lyimo, and W. Bewket, "Soil and water conservation effects on soil properties in the middle Silluh valley, northern Ethiopia," International Soil and Water Conservation Research, vol. 5, no. 3, pp. 231-240, 2017.

[6] K. Hurni, G. Zeleke, M. Kassie et al., "Soil degradation and sustainable land management in the rainfed agricultural areas of Ethiopia: an assessment of the economic implications," Report for the Economics of Land Degradation Initiative, 2015.

[7] H. Hurni, S. Abate, A. Bantider et al., "Land degradation and sustainable land management in the Highlands of Ethiopia," in Global Change and Sustainable Development: A Synthesis of Regional Experiences from Research Partnerships. Perspectives of the Swiss National Centre of Competence in Research (NCCR) NorthSouth, University of Bern, H. Hurni and U. Wiesmann, Eds., Geographica Bernensia, Bern, Switzerland, pp. 187-207, 2010.

[8] J. Nyssen, J. Poesen, J. Moeyersons, J. Deckers, M. Haile, and A. Lang, "Human impact on the environment in the Ethiopian and Eritrean highlands-a state of the art," Earth-Science Reviews, vol. 64, no. 3-4, pp. 273-320, 2004.

[9] A. Bekele, A. Aticho, and E. Kissi, "Assessment of community based watershed management practices: emphasis on technical fitness of physical structures and its effect on soil properties in Lemo district, Southern Ethiopia," Environmental System Research, vol. 7, p. 20, 2018.

[10] T. K. Alexandridis, A. M. Sotiropoulou, G. Bilas, N. Karapetsas, and N. G. Silleos, "The effects of seasonality in 
estimating the C-factor of soil erosion studies," Land Degradation \& Development, vol. 26, no. 6, pp. 596-603, 2015.

[11] N. Haregeweyn, A. Tsunekawa, J. Nyssen et al., "Soil erosion and conservation in Ethiopia," Progress in Physical Geography: Earth and Environment, vol. 39, no. 6, pp. 750-774, 2015.

[12] M. Tadesse and K. Belay, "Factors influencing the adoption of soil conservation in southern Ethiopia: the case of Gunnuno," Journal of Agriculture and Rural Development in the Tropics and Subtropics, vol. 105, no. 1, p. 132, 2004.

[13] A. Tadele, T. Aemro, G. Yihenew, Y. Birru, W. Bettina, and H. Hurni, "Soil properties and crop yields along the terraces and toposequece of Anjeni watershed, central highlands of Ethiopia," Journal of Agriculture Research, vol. 5, no. 2, 2013.

[14] A. M. Gelaw, B. R. Singh, and R. Lal, "Soil organic carbon and total nitrogen stocks under different land uses in a semi-arid watershed in Tigray, Northern Ethiopia," Agriculture, Ecosystems \& Environment, vol. 188, pp. 256-263, 2014.

[15] G. Taye, J. Poesen, B. V. Wesemael et al., "Effects of land use, slope gradient, and soil and water conservation structures on runoff and soil loss in semi-arid Northern Ethiopia," Physical Geography, vol. 34, no. 3, pp. 236-259, 2013.

[16] Z. Adimassu, K. Mekonnen, C. Yirga, and A. Kessler, "Effect of soil bunds on runoff, soil and nutrient losses, and crop yield in the central highlands of Ethiopia," Land Degradation \& Development, vol. 25, no. 6, pp. 554-564, 2014.

[17] M. Belayneh, T. Yirgu, and D. Tsegaye, "Current extent, temporal trends, and rates of gully erosion in the Gumara watershed, Northwestern Ethiopia," Global Ecology and Conservation, vol. 24, Article ID e01255, 2020.

[18] B. C. Tarekegn, "A case study of gully erosion in the Ethiopian highlands: the Warke watershed," Master's Thesis, Cornell University, Ithaca, NY, USA, 2012.

[19] B. Shiferaw, J. Okello, and V. R. Reddy, "Challenges of adoption and adaptation of land and water management options in smallholder agriculture: synthesis of lessons and experiences," in Rain Feed Agriculture: Unlocking the Potential, S. P. Wani, J. Rockstron, and T. Y. Oweis, Eds., CAB International, Wallingford, UK, 2009.

[20] M. Guadie, E. Molla, M. Mekonnen, and A. Cerdà, "Effects of soil bund and stone-faced soil bund on soil physicochemical properties and crop yield under rain-fed conditions of Northwest Ethiopia," Land, vol. 9, no. 1, p. 13, 2020.

[21] G. Gebregzibeher, D. Abera, G. Gebresamuel, M. Giordano, and S. Langan, An Assessment of Integrated Watershed Management in Ethiopia, International Water Management Institute (IWMI), Colombo, Sri Lanka, 2016.

[22] E. Kato, C. Ringler, M. Yesuf, and E. Bryan, "Soil and water conservation technologies: a buffer against production risk in the face of climate change? Insights from the Nile basin in Ethiopia," Agricultural Economics, vol. 42, no. 5, pp. 593-604, 2011.

[23] W. Mekuria, E. Veldkamp, M. Haile, J. Nyssen, B. Muys, and K. Gebrehiwot, "Effectiveness of exclosures to restore degraded soils as a result of overgrazing in Tigray, Ethiopia," Journal of Arid Environments, vol. 69, no. 2, pp. 270-284, 2007.

[24] A. Mekuriaw, A. Heinimann, G. Zeleke, and H. Hurni, "Factors influencing the adoption of physical soil and water conservation practices in the Ethiopian highlands," International Soil and Water Conservation Research, vol. 6, no. 1, pp. 23-30, 2018.

[25] D. C. Dagnew, C. D. Guzman, A. D. Zegeye et al., "Impact of conservation practices on runoff and soil loss in the subhumid Ethiopian highlands: the Debre Mawi watershed,"
Journal of Hydrology and Hydromechanics, vol. 63, no. 3, pp. 210-219, 2015.

[26] D. M. Moges and H. G. Bhat, "Watershed degradation and management practices in north-western highland Ethiopia," Environmental Monitoring and Assessment, vol. 192, no. 10, p. 664, 2020.

[27] Environment for Development, "Green accounting puts price on Ethiopian soil erosion and deforestation," 2010, http:// www.efdinitiative.org/our-work/policy-interactions/greenaccounting-puts-price-ethiopian-soil-erosion-and-deforestation.

[28] N. Haregeweyn, A. Tsunekawa, J. Poesen et al., "Comprehensive assessment of soil erosion risk for better land use planning in river basins: case study of the upper blue Nile River," Science of the Total Environment, vol. 574, pp. 95-108, 2017.

[29] M. Belayneh, T. Yirgu, and D. Tsegaye, "Runoff and soil loss responses of cultivated land managed with graded soil bunds of different ages in the upper blue Nile basin, Ethiopia," Ecological Processes, vol. 9, no. 1, pp. 1-18, 2020.

[30] S. D. Walie and G. Fisseha, "Perception of farmers toward physical soil and water conservation structures in Wyebla watershed, Northwest Ethiopia," World Journal of Agricultural Sciences, vol. 12, no. 1, pp. 57-63, 2016.

[31] Y. Ademe, T. Kebede, A. Mullatu, and T. Shafi, "Evaluation of the effectiveness of soil and water conservation practices on improving selected soil properties in Wonago district, Southern Ethiopia," Journal of Soil Science Environmental Management, vol. 8, no. 3, pp. 70-79, 2017.

[32] M. Belayneh, T. Yirgu, and D. Tsegaye, "Effects of soil and water conservation practices on soil physicochemical properties in Gumara watershed, upper blue Nile Basin, Ethiopia," Ecological Processes, vol. 8, p. 36, 2019.

[33] M. Temesgen, S. Uhlenbrook, B. Simane et al., "Impacts of conservation tillage on the hydrological and agronomic performance of Fanya juus in the upper Blue Nile (Abbay) river basin," Hydrology and Earth System Sciences, vol. 16, no. 12, pp. 4725-4735, 2012.

[34] Food and Agriculture Organization, The Digital Soil Map of the World, Land and Water Development Division Food and Agricultural Organization of United Nations, Rome, Italy, 2007.

[35] Central Statistics Authority, Summary and Statistical Report of the Population and Housing Census, Population Census Commission, Addis Ababa, Ethiopia, 2007.

[36] C. A. Black, D. D. Evans, J. L. White, L. E. Ensminger, and F. E. Clark, Methods of Soil Analysis. Part 1.Physical and Mineralogical Properties, Including Statistics of Measurement and Sampling, American Society of Agronomy, Madison, WI, USA, 1965.

[37] D. Sakar and A. Haldar, Physical and Chemical Method in Soil Analysis: Fundamental Concepts of Analytical Chemistry and Instrumental Techniques, New Age International (P) Ltd Publisher, New Delhi, India, 2005.

[38] L. P. Van Reeuwijk, Procedures for Soil Analysis: Wageningen, International Soil Reference and Information Centre, Wageningen, The Netherlands, 2002.

[39] H. Liu, Comparing Welch's ANOVA, A Kruskal-Wallis Test and Traditional ANOVA in Case of Heterogeneity of Variance, Virginia Commonwealth University, Richmond, VA, USA, 2015.

[40] L. Tiki, M. Tadesse, and F. Yimer, "Effects of integrating different soil and water conservation measures into hillside area closure on selected soil properties in Hawassa Zuria 
district, Ethiopia," Journal of Soil Science and Environmental Management, vol. 6, no. 10, pp. 268-274, 2015.

[41] M. Demelash and K. Stahr, "Assessment of integrated soil and water conservation measures on key soil properties in South Gonder, North Western highlands of Ethiopia," Journal of Soil Science and Environmental Management, vol. 1, no. 7, pp. 164-176, 2010.

[42] Z. Siraw, W. Bewket, and M. A. Degefu, "Effects of community-based watershed development on landscape greenness and vegetation cover in the northwestern highlands of Ethiopia," Earth Systems and Environment, vol. 4, no. 1, pp. 245-256, 2020.

[43] M. Eyayu, G. Heluf, M. Tekalign, and A. Mohammed, "Effects of land use change on selected soil properties in the Tara Gedam catchment and adjacent agro-ecosystems, Northwest Ethiopia," Ethiopian Journal of Natural Resources, vol. 11, no. 1, pp. 35-62, 2009.

[44] K. T. Osman, Soils: Principles, Properties and Management, Springer, Dordrecht, The Netherlands, 2013.

[45] D. Teressa, "The effectiveness of stone bund to maintain soil physical and chemical properties: the case of Weday watershed, east Hararge, Ethiopia," Civil and Environmentral Research, vol. 9, pp. 9-16, 2017.

[46] T. Sinore, E. Kissi, and A. Aticho, "The effects of biological soil conservation practices and community perception toward these practices in the Lemo district of Southern Ethiopia," International Soil and Water Conservation Research, vol. 6, no. 2, pp. 123-130, 2018.

[47] J. R. Landon, Booker Tropical Soil Manual: A Handbook for Soil Survey and Agricultural Land Evaluation in the Tropics and Subtropics, Routledge, London, UK, 2013.

[48] Y. Selassie, F. Anemut, and S. Addisu, "The effects of land use types, management practices and slope classes on selected soil physico-chemical properties in Zikre watershed, NorthWestern Ethiopia," Environmental System Research, vol. 4, p. 3, 2015.

[49] G. Heluf and N. Wakene, "Impact of land use and management practices on chemical properties of some soils of Bako area, Western Ethiopia," Ethiopian Journal of Natural Resources, vol. 8, pp. 177-197, 2006.

[50] L. B. Asmamaw and A. A. Mohammed, "Effects of slope gradient and changes in land use/cover on selected soil physic-biochemical properties of the Gerado catchment, north-eastern Ethiopia," International Journal of Environmental Studies, vol. 70, no. 1, pp. 111-125, 2012.

[51] N. Dabi, K. Fikirie, and T. M. Beyene, "Soil and water conservation practices on crop productivity and its economic implications in Ethiopia," Asian Journal of Agricultural Research, vol. 11, 2017.

[52] S. D. Walie, "Evaluate the quality of physical soil and water conservation structures in wyebla watershed, northwest Ethiopia," Journal of Environment and Earth Science, vol. 6, no. 3, 2016.

[53] M. Nael, H. Khademi, and M. A. Hajabbasi, "Response of soil quality indicators and their spatial variability to land degradation in central Iran," Applied Soil Ecology, vol. 27, no. 3, pp. 221-232, 2004. 